\title{
MDM2 Antagonist ASTX295
}

National Cancer Institute

\section{Source}

National Cancer Institute. MDM2 Antagonist ASTX295. NCI Thesaurus. Code C162749.

An orally available, small molecule inhibitor of the human homolog of murine double minute 2 (MDM2; HDM2), with potential antineoplastic activity. Upon oral administration, MDM2 antagonist ASTX295 targets and binds to MDM2 protein and prevents its binding to the transcriptional activation domain of the tumor suppressor protein $\mathrm{p53}$. This prevents p53 proteasomal degradation and restores the transcriptional activity of p53. This leads to p53-mediated induction of apoptosis in cancers with a wild-type p53 gene. MDM2, an E3 ubiquitin ligase, regulates the level and activity of p53. 